\title{
Innovations in education in the process of distance learning based on digital technologies
}

\author{
Elena Goryacheva ${ }^{1 *}$, and Olga Kartavtseva ${ }^{2}$ \\ ${ }^{1}$ Don State Technical University, 344002, Rostov-on-Don, Russia \\ ${ }^{2}$ Southern Federal University, 344000, Rostov-on-Don, Russia
}

\begin{abstract}
The article discusses innovative approaches to solving the problem of art education in the process of online learning based on digital technologies. The authors proposed their method. The relevance of the problem considered in the article is due to several reasons: Covid-19 pandemic in Russia; the emergence of new digital technologies in education; a significant increase of the flow of visual information, also associated with art. The author's method is based on innovative approaches to the system of creation of professional, psychological, pedagogical, and artistic technologies in an online form, the development of digital learning techniques, and professional tools in the interaction of a pedagogue and students. A part of art education that requires the close consideration of art technological elements also requires continuous cooperation of the pedagogue and students for the transfer and assimilation of professional skills. It is necessary to control the work process with close attention to the techniques of performing a creative task in any field of artistic and creative activity. The author's method was developed by the didactic concept of teaching based on digital technologies, psychological and pedagogical concepts of personality-oriented education. It is also based on the didactic principles of science, clarity, the connection of theory and practice activity, the sequence of learning from simple to complex, and problem-based learning. The structure and criteria for evaluating the process of remote artistic activity of students and its results are developed.
\end{abstract}

\section{Introduction}

The last 2020-2021 years have adjusted the education system. The government's plan for the transition to online digital education is being actively implemented in the process of modernizing higher professional education at the time of restrictions associated with the pandemic. It offers the use of online courses and video tutorials in a digital educational environment, the use of online resources, libraries, and other opportunities for students to obtain professional information [1], [2].

Due to the current conditions and the specifics of the subjects studied in Russia during the 2020-2021 pandemic, art education required the introduction of special adjustments in online learning, professional support of the educational process in the electronic environment.

\footnotetext{
* Corresponding author: eagorva@yandex.ru
} 
In online learning, it is necessary to convey all important components for the successful mastering of artistic disciplines. It needs such aspects as electronic equipment, an introductory part with the topic of the lesson and the requirements for completing the task, demonstration of visual materials, the organization of step-by-step, work on the task, control over the implementation of the stages after a certain time, in the task execution techniques defined by the plan; correct use of art materials and technologies for working with them. It is necessary to have computer and electronic equipment, basic skills in using electronic media, the availability of the Internet, and sending photos with the results of educational activities in the format of a sheet or a three-dimensional form according to the stages of implementation.

The hypothesis of this research can be defined as the need to develop methodological equipment to solve the problem of online learning. This need is due to the fragmentation of teaching methods in modern art professional education, which stimulate and authorize students to carry out the online learning process, most fully, become interested and active creative personalities, independently use the tools for professional and creative opportunities to optimally synthesize the practical experience of visual activity, provided by a theoretical base under the supervision of the teacher.

The object of the research is the process of art students' online learning in professional disciplines, the connection between theory and practice, visualization of work stages, and analysis of their educational and creative activities.

The subject of the research is the methodological organization of the online learning process of art disciplines: drawing, technical drawing, painting, composition, sculpture, and modeling.

The experiment involved 4 groups of students of the artistic and technological direction of the 1 st and 2nd year. 2 groups studying the art of metalwork, and 2 groups - the artistic ceramics- and glasswork.

\section{Materials and methods}

There are researches of how important each practice is in every creative profession, conveyed by the teacher in the process of explaining the stages of work in the classroom, in a master class, and in other practical types of work, in which the basics of the skill of a future artist, sculptor, actor, dancer are developed. For this group of specialists, the practical development of professional activity is the basis of mastery, while the role of theoretical material is not diminished.

The role of the pedagogue in organizing the methodological process of the educational artificial space, the problematic nature of teaching, and visual information during classes is important. As J. Elkins notes: "Visualization is not only a product of culture but its agent." He considered the variety of arts from historically established traditional to modern moving $[3$, p. 5]. The research used materials from the psychological and pedagogical concepts of leading scientists on the development of student-centered learning (E.V. Bondarevskaya, V.S.Ilyin, V.V.Serikov, I.S. Arnheim), productive perception (VP Zinchenko), unconscious in the psychology of art [4]. The impact of art is multifactorial. It develops and enriches personality through the perception of work, illustrates ethnic cultural traditions, and heals. These factors characterize personality. According to the scientist, Myasishchev V.N., personality development is also influenced by the fourth component - social relations. "The study of personality in its development represents the historical study of personality in the dynamics of its meaningful relations" [5, p. 149].

The didactic concept of teaching based on computer technology (B.S. Gershunsky, A.A. Kuznetsov, I.V. Robert, etc.), related to higher education, focuses on the formation of the personality of students, their productive activities, the intensification of the entire learning 
process. The emphasis is on providing imaginative information along with text and graphic forms through new media. [6] To help teachers, an algorithm was investigated for the implementation of the

didactic framework in online learning of students, focused on creative development and self-development in a virtual environment [7].

Pedagogues are faced with the task of organizing the sequence of the online educational process and monitoring the correct assimilation of theoretical and practical materials at a professional level, starting with a methodically organized and successfully implemented educational process, and ending with a creative attitude to completing educational and independent tasks, an interest in creating works of art and personal development student. However, the visual arts contain cultural incarnations of the artistic styles of the era, the realization of the artist's author's thought; they play the role of creating an artistic environment, perceived in society as the natural presence of various artifacts. Therefore, teachers will also have to arouse students' interest and activity in the process of their selfdevelopment.

In articles on the problem of digital education in information and communication spheres, scientists concluded that the development of a creative personality in education is associated with the field of social health and the upbringing of students' ecological behavior, and the development of a digital society in education" [8].

As a result of the analysis of these works of scientists, we formulate the following conclusions.

1. Modern pedagogy, psychology, sociology and social philosophy, physiology, art pedagogy are faced with new conditions for the education of students and the work of teachers.

2. The existing traditional base of scientific concepts and methodologies that support the learning process requires a partial renewal due to the advent of online learning.

3. In modern research in recent years, materials have been published that reveal the rationale for the current conditions of the world order and education from sociophilosophical positions, the technological features of digital education; psychological and pedagogical methods of working with students in a pandemic, problems of online art education, the importance of teaching art to different groups of the population.

In the process of online, as well as offline education, the following didactic principles of education are used:

- the principle of scientific nature, that allows applying the achievements of various related areas of scientific knowledge and their laws;

- the principle of visibility, which allows the pedagogue to provide demonstration material in the form of samples of work, illustrations of techniques, video sequences of the execution of certain stages of the assignment;

- the principle of communication between theory and practice, lecture material, theoretical recommendations of the teacher in the process of the practical lesson, and practical video used in the lesson;

- the principle of the sequence of training from simple to complex, the transition from the stage of theoretical training to the stage of practical work, as a

- combination of successive certain methods of work with the verification of their correctness, as a systematic use of them in the process of completing tasks;

- the principle of students' activity in the studying process, the activation of their creative activity, is implemented from the stage of conscious assimilation of the educational material, in the process of understanding, theory, and practice, to the stage of creative implementation of the educational task and the embodiment of ideas in the material.

International researches by scientists to study the impact of art on individuals influencing changes in society, do not lose their relevance in today, especially concerning 
the values and functions of art in society [9]. In this text, scholars have identified a wide range of the impact of art on personality in spheres of social life and its meaning.

In a description of the multidimensional and subjective nature of the experience of communication with art, the authors reveal the determinants of impact. They are subdivided into groups: "Those that are inherent in a person who interacts with a work of art; those that are inherent in a work of art; and "environmental factors" that are external to both the person and the work of art." They build a structure for the acquisition of aesthetic experience [10].

Scientists from the UK reveal the connection between art and human health. They covered a project completed in 2015. The experience of stakeholders in conducting the assessment was explored to develop online resources to increase knowledge and capacity in the arts, health, and social sectors of stakeholders. Foreign scientists pay increasing attention to combining the efforts of two social areas of activity - teaching art and its role in health care [11]. We have revealed significant factors and patterns of the influence of art in the formation of the personality of the younger generation [12]. The role of art in the creative development of the individual is emphasized by the spiritual development of the individual [13]. The development of creative thinking takes an important place in the professional organization of a positive artistic environment.

The formation of professional competencies in the field of aesthetic assessment of a work of art is carried out in the creative development of students [14], using technologies for the development of creative abilities [15], and the technology of methodological assistance in visual activity in an online education [16].

\section{Results}

Electronic communication of the Internet and information and digital support of the educational process is based on the use of the electronic educational environment of DSTU, e-mail, communication systems (WhatsApp), social networks, computers, tablets, smartphones, specialized professional sites, graphic software (composition). This approach ensures interaction and intensive educational process without interruption.

In such academic subjects as drawing, painting, composition, and sculpture, the teacher always conveys by his own example the techniques of working in the material, drawing techniques. Therewith, he keeps phasing the implementation of work from nature.

In the drawing, students must master the stages of constructing the elements of the assignment: the basics of linear perspective when constructing the foreshortening of the depicted object in space, linear constructive construction, techniques for performing hatching, working out the surface with chiaroscuro, correlation tonality of the depicted object and draping. In paintings, the last point is made with paints.

We have developed methodological approach of introducing into the studied technique that optimize the educational process. We are going to present one of them for illustration. For the successful mastering of color and color knowledge and skills in painting, we have developed the task "Performance a color palette". It is suitable for the initial stage of training or when working with new materials (gouache, acryl, watercolor). This methodological technique allows you to learn how to mix the colors of available paints from the first use of paints and brushes, and to determine all color and tonal possibilities of mixtures according to a certain system. This visual aid, created by students' own hands, will be used in every lesson until students memorize in practice how to get the color and shade of objects and details necessary for the composition. The exercise of this technique has significantly increased the degree of successful painting.

Table legend in Table 1., showing the difference in the assimilation of material in distance learning classes using digital technologies in relation to teaching in classrooms: + 
is a positive result, - is a negative result, empty column cell - is absence in this subject, Up to $50,70-\%$ are mistakes in certain professional requirements for the volume of the study assignment (as a result of the perception of a photo of the received assignment - mistakes, as a result of photographing the completed assignment and its stages - distortion of shapes and lines), Computer/telephone - a student has a computer at home/a nonresident student has a telephone in class.

Table 1. The probability of the impact of digital technologies on the effectiveness of distance learning in the fine arts disciplines.

\begin{tabular}{|c|c|c|c|c|c|c|c|c|}
\hline \multirow{2}{*}{$\begin{array}{l}\text { Professional } \\
\text { Requirements }\end{array}$} & \multicolumn{5}{|c|}{ Academic subjects } & \multirow[b]{2}{*}{$\begin{array}{l}\frac{0}{2} \\
\frac{d}{0} \\
\frac{\sqrt[\pi]{\pi}}{9}\end{array}$} & \multirow[b]{2}{*}{$\begin{array}{l}\int_{0}^{0} \\
.0 \\
.00 \\
0 \\
0 \\
0 \\
0\end{array}$} & \multirow[b]{2}{*}{ : } \\
\hline & 离 & 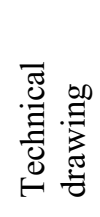 & 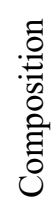 & . & 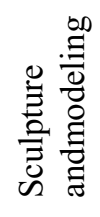 & & & \\
\hline $\begin{array}{l}\text { Compositional } \\
\text { characteristic }\end{array}$ & + & + & + & + & + & & & \multirow{7}{*}{ 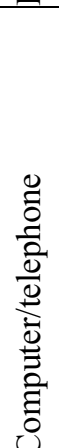 } \\
\hline $\begin{array}{l}\text { Linear- } \\
\text { constructive } \\
\text { composition }\end{array}$ & +- & +- & + & + & & Up to 50 & Up to 30 & \\
\hline Shape & + & + & + & + & - & Up to 50 & Up to 30 & \\
\hline $\begin{array}{l}\text { Light- } \\
\text { tonesolution }\end{array}$ & + & + & - & - & & & & \\
\hline Texture & + & + & + & + & - & & & \\
\hline Environment & + & + & + & + & + & & & \\
\hline Color & & & - & - & & Up to 70 & Up to 70 & \\
\hline
\end{tabular}

According to the research, students received methodological recommendations during distance learning. These recommendations make it possible to avoid negative factors in the process of preparing and sending educational material.

At the beginning of the lesson, along with theoretical and visual material, we suggest that the teacher, if necessary, apply a pedagogical drawing - a short up to 5 minutes educational material illustrated on a board/sheet, complementing the explanation.

With electronic devices - two smartphones, it is possible to record a short or long master class of a teacher with a video demonstration that reveals complex technological methods for completing the task. It is important to show close-ups of the steps and techniques for completing such an assignment.

Demonstration on the screen of a master class of an artist known for his professional skill will also help to master complex elements of work and complete the task faster.

In the online art teaching, the difficulty lies in the students' implementation and the teacher's verification of the technique of each of the sequential stages of the work, as well as a detailed study of all techniques at a close distance from the working surface. Mastering the work with a pencil: tilt, hatching, direction ofmovement of the hand and the position of the fingers on the pencil, periodic processing of the lead - all ofthese detailed technological techniques represent the basics of skills for working on an educational professional drawing.

Visual component in the form of sample drawings for online artistic activity is a necessary part of the educational process. 
Feedback is also needed to control the student's work. For this, the following are applicable: video materials with a close-up of the task being performed, photos with no distortion in the work performed, sent by the student to the teacher during the distance lesson.

\section{Discussion}

For a successful educational process, it is important to clearly identify and observe the stages of work on a full-scale staging, so that students do all work in a technological sequence, without disrupting the process to the detriment of the result of the work. For the art specialty, during the period of distance learning, it is essential to have the opportunity to examine in detail the techniques that contain the basics of knowledge in the subject under study. In such classes, the student acquires and accumulates professional experience and competencies. Discipline in the classroom is required. The student must immediately provide a photo or video of the work at the request of the teacher for a stepwise check of its implementation, correct errors according to the indicated comments, leave the contact only upon completion of the educational process. The work should be done according to the time calculated for the classroom, despite the use of digital technology. Here it is important to organize the clarity of the educational process and, as mentioned earlier, the relationship between the teacher and the student.

Painting for distance learning is a more complex subject, because even with all the proven techniques for successful classes, digital technologies do not allow to convey the color scheme of individual objects, their details, and the general color exactly with the colors of the setting. Depending on the painting material: acryl, gouache or watercolor, additional difficulties appear in monitoring compliance with the rules and techniques for working with paints. As specialists in the field of artistic pedagogy, we had to solve the problems of developing a methodology for a successful educational process, the formation of students' activity and interest in professional education and the formation of a creative personality, participation in creative projects. Painting training according to our methodology gave a positive result in the intensification of the learning process and creative artistic object-oriented activity.

To analyze the results of the author's methodology, surveys of teachers and students were used; work performed by students, clarification of working conditions, technical equipment with digital equipment, and the Internet.

The applied optimization of distance, classroom, and independent educational process led to the intensity of educational and creative activities in online and offline learning. In addition, it had a positive influence on the level of training of students and further motivation, and on the development of interest in an in-depth study of the art disciplines.

Creative works clearly demonstrate professional and competence growth in the use of tools and object-oriented activity.

The result of students' creative reflection was theoretical research: contributions, articles; creative works: participation in offline and online exhibitions.

We assume the further application of the developed methodology in the educational process, which requires a study and a detailed description of the results of the application of this author's method in other disciplines of the art cycle that we have indicated. 


\section{Conclusions}

Innovations in art education in the process of distance learning based on digital technologies are not only mastering the skills of working in electronic systems, but also the formation of a new type of personality, a creative personality capable of innovation.

A creative personality is characterized by great mental mobility, adaptation to the frequently changing conditions of the educational process, the ability to master digital technologies. Creative personality realizes new opportunities in visual communications, forms new competencies in accordance with the modernization of education.

Informational and digital support of the educational process are based on the use of the electronic information and educational environment of the DSTU, e-mail, social networks, computers, tablets, graphic software. The use of these means is innovative in art education in the process of distance learning, along with the developed methodological techniques that optimize the educational process.

In the online learning the role of a teacher is still important - he exercises control over the entire educational process and assignments. The role of the teacher is to summarize at the end of the lesson, to identify mistakes and advantages, to indicate successful places in the work performed. The teacher guides the student towards the correct techniques of student work, so that he further gains increasing confidence in his foundations of mastery, which can develop creatively both in distance learning and in classroom studies, as well as in an independent creative process. Uncertainty about one's artistic abilities interferes with an impactful learning process.

In the pedagogical process, it is important to remember about the constant formation of the student's creative personality. For this, it is necessary to organize and support the participation of students in exhibitions with the best classroom and solitary work performed under the guidance of a teacher.

The educational technologies considered in the article can be used in training artists, designers, technologists of shaping as well as artistic processing of materials.

\section{References}

1. Modern digital educational environment in the Russian Federation (2016-2021). URL: http://government.ru/8SiLmMBgjAN89vZbUUtmuF51ZYfTvOAG.pdf

2. National project "Education". URL: https://edu.gov.ru/national-project

3. J. Elkins, E. Fiorentini, Visual Worlds. Looking, Images, Visual Disciplines (Oxford University Press, New York, 2020).

4. E.R. Kandel, The Age of Insight: The Quest to Understand the Unconscious in Art (Mind and Brain from Vienna 1900 to the Present, Random House, New York, 2012).

5. V.H. Myasishchev, Psychology of Relationships. 4nd edn (MODEK, Voronezh, 2011).

6. I.V. Robert, Institute of Informatization of Education of the Russian Academy of Education 274, 79 (2008).

7. T.A. Goriainova, D.M. Kolomyts, I.G. Kartushina, E.S. Minkova, I.V. Garifullina, I.N. Dubovitsky, O.V. Hlusyanov, EurAsian Journal of BioSciences 14 (1), 1233-1240 (2020).

8. V.A. Zakharova, I.V. Chernov, T. Nazarenko, P.V. Pavlov, V.S. Lyubchenko, A.A. Kulikova, Cypriot Journal of Educational Sciences 15 (5), 1288-1294 (2020). doi: 10.18844/cjes.v15i5.5167

9. E. Belfiore, O. Bennett, The Social Impact of the Arts: An Intellectual History (Palgrave Macmillan, London, 2008). doi: 10.1057/9780230227774 
10. E. Belfiore, O. Bennett, Cultural Trends 16 (3), 225-275 (2007). doi: $10.1080 / 09548960701479417$

11. N. Daykin, K. Gray, M. McCree, J. Willis, Arts \& Health 9 (2), 123-138 (2017). doi: 10.1080/17533015.2016.1206948

12. E.A. Goryacheva, Yu.S. Ushaneva, Social and humanitarian knowledge 11, 75-81 (2017).

13. O.D. Kartavceva, Spiritual development of personality based on self-realization of essential forces in creativity (IPO PI YUFU, Rostov-on-Don, 2009).

14. I. Vlasova, Y. Ushanyova, S. Pisarenko, Innovative Technologies in Science and Education (ITSE-2020), E3S Web of Conferences 210, 22027 (2020). doi: $10.1051 / \mathrm{e} 3$ sconf $/ 202021022027$

15. I. Protopopova, O. Kartavtseva, Innovative Technologies in Science and Education (ITSE-2020), E3S Web of Conferences 210, 22015 (2020). doi: $10.1051 / \mathrm{e} 3$ sconf $/ 202021022015$

16. N. Zakharova, I. Vlasova, O. Kartavtseva, Technologies of tutorial assistance in the visual activity distance education for the bachelors-designers, Innovative Technologies in Science and Education (ITSE-2020), E3S Web of Conferences 210, 22014 (2020). doi: $10.1051 / \mathrm{e} 3 \operatorname{sconf} / 202021022014$ 